\title{
Faktor-Faktor Yang Mempengaruhi Subjective Well-Being Pada Ibu Jalanan
}

\author{
Fitrianur, Nina Zulida Situmorang, Fatwa Tentama \\ Magister Psikologi Universitas Ahmad DahlanYogyakarta \\ mbak_rie@yahoo.com \\ nina.situmorang@psy..uad.ac.id \\ fatwa.tentama@psy.uad.ac.id
}

\begin{abstract}
Abstrak
Ibu jalanan merupakan salah satu dari kelompok rentan, yaitu orang-orang yang mudah tertindas, berisiko tereksploitasi, dan sering terabaikan oleh program pemerintah. Hidup sebagai ibu jalanan bukan suatu pilihan yang menyenangkan, banyak tekanan yang harus dihadapi saat mereka menjalani peran gandanya, yaitu berjuang melayani keluarganya di tempat tinggal dan mencari nafkah untuk menopang kebutuhan keluarga di jalanan. Banyaknya tekanan hidup yang mereka hadapi dapat berdampak pada kondisi psikologis, salah satunya tingkat subjective well-being yang dimilikinya. Subjective well-being adalah evaluasi subjektif seseorang terhadap hidupnya yang meliputi komponen kepuasan hidup, afek positif, dan afek negatif. Berbagai faktor dapat mempengaruhi tingkat subjective wellbeing seseorang. Kajian dari paper ini menunjukkan bahwa pendapatan, religiusitas, kebersyukuran, kepribadian, dan dukungan sosial dapat mempengaruhi subjective well-being pada ibu jalanan.
\end{abstract}

Kata kunci: ibu jalanan, kebahagiaan, subjective well-being

\section{Pendahuluan}

Ibu jalanan sebagai perempuan dewasa sejatinya menjalankan tugas perkembangan dengan normal, tapi di sisi lain ia juga harus menghadapi kompleksitas masalah kehidupan, antara lain tingkat sosial ekonomi yang rendah, pendidikan yang rendah, harus menjalani pekerjaannya di jalanan dikarenakan penghasilan suami yang tidak dapat mencukupi kebutuhan sehari-hari atau ia merupakan orangtua tunggal yang harus membesarkan ankanaknya. Menurut teori perkembangan yang dikemukakan oleh Erik Erikson jika pada masa dewasa awal seseorang menjalani kehidupan penuh dengan masalah, terkucilkan, dan tidak mendapatkan kasih sayang yang cukup maka akan berakibat pada kondisi psikologis yang negatif yaitu apatis atau tidak peduli dengan orang lain (Santrock, 2014).

Ibu jalanan juga merupakan salah satu kategori yang termasuk kelompok rentan karena ia sebagai perempuan dan tergolong penduduk miskin, serta memiliki beberapa karakteristik seperti cenderung tidak berdaya (tidak memiliki kekuasaan) di masyarakat, berisiko terekploitasi secara fisik, psikis, atau emosional, dan sering terabaikan dari program pemerintah. Selain itu, berbagai masalah kehidupan yang dihadapi antara lain kemiskinan, hidup dan atau bekerja di jalanan, ada yang tidak memiliki suami, ada yang sedang hamil, 
memiliki anak usia dini, serta peran gandanya sebagai ibu, istri, dan pencari nafkah bagi keluarganya (Tentama, Pranungsari, \& Tarnoto, 2017).

Hidup sebagai ibu jalanan bukan suatu pilihan yang menyenangkan, banyak tekanan yang harus dihadapi saat mereka menjalani peran gandanya, yaitu berjuang melayani keluarganya di tempat tinggal dan mencari nafkah untuk menopang kebutuhan keluarga di jalanan. Banyaknya tekanan hidup yang mereka hadapi dapat berdampak pada kondisi psikologis, salah satunya tingkat subjective well-being yang dimilikinya.

Subjective well-being merupakan gambaran luas yang mengacu pada semua bentuk mengenai evaluasi kehidupan seseorang atau pengalaman emosionalnya, seperti kepuasan, afek positif, dan rendahnya afek negatif (Diener, Oishi, \& Lucas, 2015). Komponen afektif berkaitan dengan pengalaman seseorang mengenai afek positif, seperti kegembiraan, kebersyukuran, dan kebermaknaan dan afek negatif seperti kemarahan, kesedihan, dan kekhawatiran. Komponen kognitif mengacu pada kepuasan hidup seseorang (Diener, et.al, 2015).

Subjective well-being merupakan hal yang penting untuk dipelajari dan diteliti bukan hanya karena menggambarkan kualitas hidup seseorang, tapi juga dapat memberikan dampak positif dalam kehidupan. Salah satu manfaat positif memiliki level subjective well-being yang tinggi adalah manfaat terhadap kesehatan dan daya tahan tubuh, dimana orang yang bahagia cenderung lebih sehat, tidak mudah sakit, cenderung berumur panjang, dan dapat mengontrol diri (Diener \& Chan, 2011).

Berdasarkan latar belakang yang telah dipaparkan, paper ini dibuat untuk menjelaskan faktor apa saja yang dapat mempengaruhi subjective well-being pada ibu jalanan melalui beberapa tahap yaitu mencari dan menyeleksi berbagai hasil penelitian yang terkait, kemudian menganalisis dan mensintesis temuan-temuan dalam penelitian, dan menyusunnya menjadi paper.

\section{Subjective Well-Being}

Subjective well-being merupakan gambaran luas yang mengacu pada semua bentuk mengenai evaluasi kehidupan seseorang atau pengalaman emosionalnya, yang meliputi kepuasan, afek positif, dan rendahnya afek negatif (Diener, Oishi, \& Lucas, 2015). Veenhouven (2011) menjelaskan bahwa subjective well-being merupakan tingkat di mana seseorang menilai kualitas kehidupannya sebagai sesuatu yang diharapkan dan merasakan perasaan yang menyenangkan. 
Subjective well-being dimaknai sebagai evaluasi kehidupan (life evaluation) yang dirasakan seseorang terhadap aspek kehidupan tertentu maupun kehidupannya secara keseluruhan dengan juga mempertimbangkan perasaan (affect) yang mencakup pengalaman emosional yang dialami, dan eudaimonia (flourishing/eudaimonic) yang mengacu pada fungsi psikologi seseorang yang dapat berjalan dengan baik (OECD, 2013).

Komponen afektif berkaitan dengan reaksi afektif seseorang saat mengevaluasi kondisi dan peristiwa di dalam hidupnya dan terbagi menjadi dua, yaitu afek positif dan afek negatif. Afek positif adalah emosi-emosi yang merefleksikan reaksi seseorang terhadap peristiwa-peristiwa yang menunjukkan bahwa hidup berjalan sesuai dengan apa yang ia inginkan, misalnya tertarik atau berminat akan sesuatu (interested), gembira (excited), kuat (strong), antusias (enthusiastic), waspada atau siap siaga (alert), bangga (proud), bersemangat (inspired), penuh tekad (determined), penuh perhatian (attentive), dan aktif (active). Afek negatif merefleksikan respon negatif yang dialami seseorang sebagai reaksinya terhadap keadaan dan peristiwa yang mereka alami, misalnya sedih atau susah (distressed), kecewa (disappointed), bersalah (guilty), takut (scared), bermusuhan, (hostile), lekas marah (irritable), malu (shamed), gelisah (nervous), gugup (jittery), dan khawatir (afraid) (Diener, et.al, 2015).

Komponen subjective well-being lainnya adalah komponen kognitif yang mengacu pada kepuasan hidup seseorang, terdiri dari kepuasan hidup secara global (life satisfaction), yaitu evaluasi responden terhadap kehidupannya secara menyeluruh dan kepuasan pada domain tertentu seperti kesehatan fisik dan mental, pekerjaan, rekreasi, hubungan sosial dan keluarga. Kedua komponen tersebut tidak sepenuhnya terpisah.

Berdasarkan beberapa definisi yang telah dikemukakan tersebut, maka dapat diartikan bahwa subjective well-being adalah konsep yang mencakup pada bagaimana seseorang memikirkan, mempersepsikan, dan merasakan kehidupan mereka dalam berbagai keadaan yang terjadi dan dialami, baik secara kognitif maupun afektif.

Subjective well-being merupakan hal yang penting untuk dipelajari dan diteliti bukan hanya karena menggambarkan kualitas hidup seseorang, tapi juga dapat memberikan dampak positif dalam kehidupan. Subjective well-being berkaitan erat dengan berbagai hal penting dalam kehidupan, seperti hubungan sosial (Seligman, 2011), kesehatan fisik termasuk kematian dan usia yang panjang (Diener \& Chan, 2011), dan kesehatan mental (Diener \& Seligman, 2002). 


\section{Faktor-Faktor Yang Mempengaruhi Subjective Well-Being Pada Ibu Jalanan}

\section{Pendapatan}

Walaupun masih banyak perdebatan dikalangan peneliti, beberapa penelitian menunjukkan bahwa pendapatan seseorang berpengaruh pada tingkat subjective well-being yang dimilikinya (Howell \& Howell, 2008; Howell, Kern, \& Lyubomirsky, Lucas \& Schimmack, 2007; Diener \& Diener, 2002). Penelitian lain juga menunjukkan bahwa ada hubungan antara pendapatan dengan satu atau lebih dari tiga komponen subjective well-being (kepuasan hidup, aspek positif, dan aspek negatif) (Lucas, Diener, \& Suh, 2007).

\section{Religiusitas}

Penelitian yang dilakukan Ashari dan Dahriyanto (2016) pada penduduk miskin menunjukkan bahwa kebahagiaan dipengaruhi oleh tingkat religiusitas yang digambarkan dengan kualitas ketaatan beribadah atau hubungan dengan Tuhan, dan partisipasi individu dalam kegiatan religius dan peribadatan. Individu yang memiliki kualitas ketaatan beribadah dan hubungan dengan Tuhan yang baik cenderung memiliki tingkat subjective well-being yang tinggi. Penelitian lain juga menjelaskan bahwa orang yang selalu terlibat aktivitas religius dan rajin beribadah cenderung memiliki akhlaq yang baik, sopan dalam bergaul, dan mampu mengendalikan stres dalam hidup sehingga tingkat subjective well beingnya tinggi (Eryilmasz, 2015). Holder, Coleman, dan Wallace (2010) juga menjelaskan bahwa religiusitas memiliki pengaruh terhadap tingkat subjective well-being seseorang.

\section{Kebersyukuran}

Penelitian yang dilakukan oleh Robustelli dan Whisman (2018) menunjukkan bahwa kebersyukuran memiliki korelasi positif terhadap subjective well-being, yaitu pada komponen kepuasan hidup pada domain hubungan sosial, pekerjaan, dan kesehatan, serta kepuasan hidup secara global di Amerika dan Jepang. Penelitian yang dilakukan oleh Sapmaz, Yıldırım, Topçuoğlu, Nalbant, dan Sızır (2016) juga menunjukkan bahwa kebersyukuran memiliki korelasi positif secara sgnifikan dengan kebahagiaan. Penelitian lain juga menunjukkan bahwa kebersyukuran memiliki hubungan dengan subjective well-being (Chan, 2013).

\section{Kepribadian}

Soto (2013) menyatakan bahwa tingkat subjective well-being yang tinggi berhubungan dengan tingginya tingkat Ekstraversion, Agreeableness, dan Conscientiousness, serta rendahnya tingkat Neuroticism. Tatarkiewicz (Diener 1984) menyatakan bahwa kepribadian merupakan hal yang paling berpengaruh terhadap subjective well-being dibandingkan dengan faktor lainnya. Hal ini dikarenakan beberapa variabel kepribadian 
menunjukkan kekonsistenan dengan subjective well-being, diantaranya self esteem. Pada saat orang mengalami ketidakbahagiaan ternyata self esteem ini juga dalam keadaan menurun (Laxer dalam Diener, 1984).

\section{Dukungan sosial}

Menurut penelitian yang dilakukan Amalia (2014), dukungan sosial (social support) meliputi aspek emotional support, instrumental support, informational support, dan appraisal support, memiliki korelasi positif dengan kebahagiaan. Li, Yu, dan Zhou (2014) juga menjelaskan bahwa dukungan sosial memiliki hubungan langsung yang signifikan dengan subjective well-being.

\section{Kesimpulan}

Subjective well-being adalah evaluasi subjektif seseorang terhadap hidupnya yang meliputi komponen kepuasan hidup, afek positif, dan afek negatif. Setiap orang, termasuk ibu jalanan memiliki subjective well-being yang sangat bervariatif dan dipengaruhi oleh berbagai faktor. Banyaknya tekanan hidup yang dihadapi oleh ibu jalanan dapat berdampak pada tingkat subjective well-being yang dimilikinya.

Berdasarkan kajian yang dilakukan terdapat faktor-faktor dapat mempengaruhi tingkat subjective well-being yaitu pendapatan, religusitas, kebersyukuran, kepribadian, dan dukungan sosial dapat mempengaruhi subjective well-being pada ibu jalanan. 


\section{DAFTAR PUSTAKA}

Amalia, S. (2014). Pengaruh dukungan sosial keluarga terhadap kebahagiaan (happiness) pada lansia di Kota Malang (Studi integratif berdasarkan perspektif hedonia dan eudaimonia). Tesis. Bandung: Universitas Padjadjaran.

Ashari, O.B., \& Dahriyanto, L.F. (2016). Apakah orang miskin tidak bahagia? Studi fenomenologi tentang kebahagiaan di Dusun Deliksari. Scientific Journal of Universitas Negeri Semarang, 8(1).

Astuti, Y., \& Anganthi, N.R.N. (2016). Subjective well-being pada remaja dari keluarga broken home. Jurnal Penelitian Humaniora, 17(2), 161-175.

Carr, A. (2011). Positive psychology: The science of happiness and human strengths. New York: Rotledge.

Chan, D. W. (2013). Subjective well-being of Hong Kong Chinese teachers: The contribution of gratitude, forgiveness, and the orientations to happiness. Teaching and Teacher Education, 32, 22-30. doi: 10.1016/j.tate.2012.12.005

Compton, W.C. (2005). An introduction to positive psychology. Thomson Wadsworth.

De Neve, J.E., Diener, E., Tay, L., \& Xuereb, C. (2013). The objective benefits of subjective well-being. In Helliwell, J., Layard, R., \& Sachs, J. Eds. World Happiness Report 2013. New York: UN Sustainable Development Solutions Network.

Diener, E., Glatzer, W., Moum, T., Sprangers, M., Vogel, J., \& Veenhoven, R. (2009). The science of well-being: The collected works of Ed Diener. New York: Spinger.

Diener, E., \& Chan, M.Y. (2011). Happy people live longer: Subjective well-being contributes to health and longevity. Applied Psychology, Health and Well-Being, 3, $1-43$.

Diener, E., Oishi, S., \& Lucas, R.E. (2015). National accounts of subjective well-being. American Psychologist, 70, 234-242.

Diener, E., \& Tay, L. (2015). Subjective well-being and human welfare around the world as reflected in the gallup world poll. International Journal of Psychology, 50(2), 135149.

Diener, E., Heintzelman, S. J., Kushlev, K., Tay, L., Wirtz, D., Lutes, L. D., \& Oishi, S. (2016). Findings all psychologists should know from the new science on subjective well-being. Canadian Psychology.

Diponegoro, A.M., \& Mulyono. (2015). Faktor-faktor psikologis yang mempengaruhi kebahagiaan pada lanjut usia Suku Jawa di Klaten. Psikopedagogia, 4(1).

Efklides, A., \& Moraitou, D. (2013). A positive psychology perspective on quality of life: Social indicators research series 51. Springer Science: Bussiness Media Dordrecht. 
Eryilmasz, A. (2015). Investigation of the relations between religious activities and subjective well-being of High School Students. Educational Sciences: Theory \& Practice, 15(2): 433-444. DOI 10.12738/estp.2015.2.2327.

Eid, M., \& Larsen, R.J. (2008). The science of subjective well being. New York: The Guilford Press.

Forgeard, M.J.C., Jayawickreme, E., Kern, M, \& Seligman, M.E.P. (2011). Doing the right thing: measuring well-being for public policy. International Journal of Wellbeing 1, 79-106.

Holder, M. D., Coleman, B., \& Wallace, J. M. (2010). Spirituality, religiousness, and happiness in children aged 8-12 years. Journal of Happiness Studies, 11(2), 131150.

Howell, R.T., Kern, M.L., \& Lyubomirsky, S. (2007). Health benefits: metaanalytically determining the impact of well-being on objective health outcomes. Health Psychol.Rev, 1, 83-136.

Howell, R.T, \& Howell, C.J. (2008). The relation of economic status to subjective well-being in developing countries: a meta-analysis. Psychol.Bull,134, 536-560.

Lewi, N., \& Sudarji, S. (2015). Faktor-faktor pendukung kebahagiaan pada empat narapidana wanita di Lapas Wanita Kelas II A Tangerang. Psibernetika, 8(2).

Li, B., Yu, F., Zhou Z. (2014). Positive psychological capital: A new approach to social support and subjective well-being. Social Behavior And Personality, 42(1), 135-144. http://dx.doi.org/10.2224/sbp.2014.42.1.135

Lucas, R.E., \& Schimmack, U. (2009). Income and well-being:how big is the gap between the rich and the poor?. Journal .Res.Pers.43, 75-78.

Lucas, R.E., Diener, E.E., \& Suh, E. (2007). Discriminant validity of well-being measures. Journal of Personality and Social Psychology, 71, 616-628.

King, L.A. (2016). Psikologi umum: Sebuah pandangan apresiatif. Petty Gina Gayatri (penerjemah). Jakarta: Salemba Humanika.

Mechanic, D., \& Tanner, J. (2007). Vulnerable people, groups, and populations. Societal View and Health Affair, 26(5), 1220-1230.

OECD (Organisation for Economic Co-operation and Development). (2013). OECD Guidelines on measuring subjective well-being. Paris: OECD Publishing.

Papalia, D.E., Olds, S.W., \& Feldman, R.D. (2013). Human development. Brian Marswendy (penerjemah). Jakarta: Salemba Humanika.

Robustelli, B.L., Whisman, M.A. (2018). Gratitude and Life Satisfaction in The United States and Japan. Journal of Happiness Stud 19, 41-55. 
Sapmaz, F., Yıldırım, M., Topçuoğlu, P., Nalbant, D., \& Sızır, U. (2016). Gratitude, Forgiveness and Humility as Predictors of Subjective Well-being among University Students. International Online Journal of Educational Sciences, 8 (1), 38-47.

Soto, C.J. (2015). Is happiness good for your personality? Concurrent and prospective relations of the big five with subjective well-being. Journal of Personality, 83: 1.

Tentama, F., Pranungsari, D., \& Tarnoto, N. (2017). Pemberdayaan komunitas anak jalanan Yogyakarta melalui bermain peran. Jurnal Pengabdian Pada Masyarakat, 2(1), 1118.

Veenhoven, R (2011). Greater happiness for a greater number: is that possible? if so, how?. Published in: Sheldon, K.M., Kashdan, T.B. \& Steger, M.F. (Eds.) Designing Positive Psychology: Taking Stock and Moving Forward. New York: Oxford University Press. 